GRADIATION\&APPLICATIONS

ISSN 2466-4294 (online) | rad-journal.org

Vol. 2 | Issue 3 | pp. 220 - 225, 2017

doi: 10.21175/RadJ.2017.03.044

Original research paper

\title{
ANALYSIS OF AEROSOLS IN INDOOR WORKING ENVIRONMENT BY X-RAY FLUORESCENCE TECHNIQUE (XRF)*
}

\author{
Marija Čargonja $^{1^{* *}}$, Gordana Žauhar'1,2, Ivica Orlić1 \\ ${ }^{1}$ Department of Physics, University of Rijeka, Croatia \\ ${ }^{2}$ Medical Faculty, Department of Medical Physics and Biophysics, University of Rijeka, Croatia
}

\begin{abstract}
In this study, fine particulate matter (PM2.5) was collected inside the metal workshop located in the suburb of the City of Rijeka, Croatia. The high intensity of welding and plasma cutting is characteristic for this metal workshop and, therefore, high levels of very fine metal aerosols were expected. The fine aerosol sampling on thin Teflon filters and subsequent XRF elemental analysis were performed. The sampling in the workshop was conducted in two sampling periods in May and November 2016. In total, 64 samples were collected, out of which 28 were 12hours samples and 36 were hourly samples. Additionally, Trotec Optical Particle Counter PC22O was used to measure concentrations for 6 different optical sizes (o.3 $\mu \mathrm{m}, 0.5 \mu \mathrm{m}, 1 \mu \mathrm{m}, 2.5 \mu \mathrm{m}, 5 \mu \mathrm{m}$ and $10 \mu \mathrm{m})$ to obtain the particle size distribution. The sample analysis was carried out with X-Ray Fluorescence technique at the Laboratory for Elemental Microanalysis at the Department of Physics, University of Rijeka. Heavy metals such as Ti, $\mathrm{Cr}, \mathrm{Mn}, \mathrm{Fe}, \mathrm{Ni}, \mathrm{Cu}, \mathrm{Zn}$ and $\mathrm{Pb}$ were detected. The results were compared to the average daily concentrations measured in the city centre. Concentrations of all measured metals in indoor air in our study were significantly higher than in the samples collected outdoors. The highest indoor/outdoor ratio was obtained for Fe and Mn. Weekly and daily variations of heavy metal concentrations were also analysed. As expected, the results showed that weekly and diurnal variations of metal concentrations follow the work intensity in the workshop. The particle size distribution shows that sub-micron particles are present in much higher concentrations than coarse particles. This indicates the harmfulness of welding fumes.
\end{abstract}

Key words: Heavy metals, metal workshop, particle size distribution, welding aerosols, working environment

\section{INTRODUCTION}

One of the most important air constituents for human health is particulate matter (PM), a mixture of particles and liquid droplets in the atmosphere. A fine fraction of aerosols, containing particles of aerodynamic diameter smaller than $2.5 \mu \mathrm{m}$, is the most harmful because it can easily enter the human respiratory system.

Many studies have been conducted to monitor the air quality in different indoor working environments, like chemical laboratories, dental clinics and metal workshops [1-3].

The ambient air in a mechanical workshop often has a high concentration of fine particles with potentially harmful composition $[1,4,5]$, causing multiple health problems [6-10]. The most important source of fine aerosols in metal workshops is welding fume, a mixture of various gases and solid particles of elements such as iron and manganese. The risk of exposure and adverse effects is primarily from inhalation of manganese. The American Conference on
Governmental Industrial Hygienists (ACGIH) advised a threshold limit value for respirable manganese of $20 \mu \mathrm{g} / \mathrm{m}^{3}$ for an average concentration measured over 8-h period.

Concentrations of fine particulate matter $\left(\mathrm{PM}_{2.5}\right)$ were monitored in a metal workshop in a suburb of the city of Rijeka, Croatia. The most important activities of this workshop are electric arc welding and plasma cutting of steel components. The aim of this research was to investigate the levels of occupational exposure of workers to heavy metals in fine particulate matter in order to examine whether it is necessary to implement additional protective measures for workers.

\section{MATERIALS AND METHODS}

\subsection{Sample collection}

To obtain elemental concentrations in $\mathrm{PM}_{2.5}$, particulate matter was collected on thin Teflon filters (Pall Corporation R2P1025, diameter of $25 \mathrm{~mm}$, pore size of $0.3 \mu \mathrm{m}$ ) using a cyclone sampler developed at

\footnotetext{
* The paper was presented at the Fifth International Conference on Radiation and Applications in Various Fields of Research (RAD 2017), Budva, Montenegro, 2017.

mcargonja@uniri.hr
} 
M. Čargonja et al., Analysis of aerosols in indoor working environment..., Rad. Applic., 2017, 2, 3, 220-225

Australian Nuclear Science and Technology Organisation (ANSTO) [11] with the average flow rate of $18 \mathrm{l} / \mathrm{min}$. This flow rate was selected because it was as close as possible to the nominal rate for the $2.5 \mu \mathrm{m}$ cut-off size.

The sampling was performed during two separated periods. From May $14^{\text {th }}$ (Saturday) to May $27^{\text {th }}$ (Thursday) 2016, 26 half-day samples were collected. Samples were collected during daytime (5AM-5PM) and night-time (5PM-5AM). The sampler was positioned in an open store-room, at a distance of at least $30 \mathrm{~m}$ from the closest welding worker.

In order to get a better time resolution during the working hours, we performed the second sampling campaign from November $13^{\text {th }}$ (Sunday) to November $17^{\text {th }}$ (Thursday) 2016. Hourly samples were collected from $6 \mathrm{AM}$ to $6 \mathrm{PM}$, while $12 \mathrm{~h}$-samples were collected from 6PM to 6AM. 12-hour sampling periods were chosen for non-working periods because the pollution during non-working time was not high enough to be measurable on hourly samples. In total, 36 hourly and four 12h-samples were collected. In this sampling period, the sampler was positioned in the workshop at the distance of about $5 \mathrm{~m}$ from the closest welding machine. The sampler inlet was positioned at the average breathing height of $1.7 \mathrm{~m}$ above the floor level. Additionally, in this sampling period the Trotec particle counter PC22O was used to obtain the particle size distribution. Aerosol number concentrations were measured for 6 optical sizes: $0.3 \mu \mathrm{m}, 0.5 \mu \mathrm{m}, 1 \mu \mathrm{m}$, $2.5 \mu \mathrm{m}, 5 \mu \mathrm{m}$ and $10 \mu \mathrm{m}$. The sampling was performed at the flow rate of $2.83 \mathrm{l} / \mathrm{min}$. It was programmed to measure the number concentrations of each size every $260 \mathrm{~s}$ but, due to some technical problems, it did not work properly through the whole sampling period.

The workshop has two floors. The welding is performed on the ground floor while the plasma cutting is placed on the first floor of the workshop. There is no ventilation, nor heating in the workshop. The usual working-time starts at 6AM and finishes at 2PM, although sometimes some additional work was often done after the usual working-time. Workers usually take a half-hour break for lunch around 11 or 12AM.

The concentrations of metals in aerosol within the workshop were compared to the average concentrations in the city center. Average elemental outdoor concentrations were obtained from the continuous aerosol monitoring which has been performed in the center of the city of Rijeka since 2013 [12].

\subsection{Analysis}

Each Teflon filter was weighted before and after the sampling to obtain the total aerosol mass. The filters were held under stable conditions $\left(22^{\circ} \mathrm{C}\right.$ and relative humidity of $19 \%$ ) for at least 24 hours before weighting with the Mettler Toledo XA105 Dual range balance (readability $10 \mu \mathrm{g}$ ).

$\mathrm{PM}_{2.5}$ samples were analyzed by Energy Dispersive X-Ray Fluorescence technique (ED-XRF) at the Laboratory for Elemental Microanalysis at the Department of Physics, University of Rijeka to obtain concentrations of eight heavy metals $(\mathrm{Ti}, \mathrm{Cr}, \mathrm{Mn}, \mathrm{Fe}$, $\mathrm{Ni}, \mathrm{Cu}, \mathrm{Zn}$ and $\mathrm{Pb}$ ). A low power rhodium $\mathrm{X}$-ray tube was used under $50 \mathrm{kV}$ and $1 \mathrm{~mA}$ and with the collimator of $2 \mathrm{~mm}$ in diameter perpendicular to the sample. A silicon drift detector positioned at $45^{\circ}$ to the sample was used to measure X-rays from the sample $[12,13]$. To avoid any inhomogeneities in the sample, area of $8 \times 8 \mathrm{~mm}^{2}(7 \times 7$ overlapping pixels) was scanned on each sample. For each sample, the sum of 49 spectra was used for further analysis. The resulting X-ray spectra were analyzed using the AXIL software [14]. In order to perform quantitative analysis, the system was previously calibrated using thin multi-elemental standards.

For the first sampling period minimum detection limit (MDL) for $\mathrm{Pb}$ was $0.0063 \mu \mathrm{g} / \mathrm{m}^{3}$ and for other elements MDL ranges from $0.0019 \mu \mathrm{g} / \mathrm{m}^{3}$ to $0.0027 \mu \mathrm{g} / \mathrm{m}^{3}$. For the second sampling period MDL for $\mathrm{Pb}$ was $0.14 \mu \mathrm{g} / \mathrm{m}^{3}$ and for other elements in range from $0.29 \mu \mathrm{g} / \mathrm{m}^{3}$ to $0.44 \mu \mathrm{g} / \mathrm{m}^{3}$.

Statistical analysis of data including Pearson correlation analysis was carried out using the Statistica 13.1 statistical software.

\section{RESULTS}

Table 1 shows the average daytime and night-time elemental and $\mathrm{PM}_{2.5}$ concentrations for the first sampling period and their ratios. Iron was found as the dominated metal followed by $\mathrm{Mn}, \mathrm{Zn}$ and $\mathrm{Cu}$. Average concentrations of metals during working day were from 4 to 23 times higher than during night-time or nonworking period. Fitting errors of concentrations ranged from $11 \%$ for $\mathrm{Cu}$ to $27 \%$ for $\mathrm{Fe}$.

Table 1. Average daytime $\left(\mathrm{C}_{\mathrm{d}}\right)$ and night-time metal concentrations $\left(\mathrm{C}_{\mathrm{n}}\right)$ their standard deviations (SD) and their ratios for the first sampling period. Concentrations are expressed in $\mu \mathrm{g} / \mathrm{m}^{3}$

\begin{tabular}{|c|c|c|c|}
\hline & $\mathrm{C}_{\mathrm{d}} \pm \mathrm{SD}$ & $\mathrm{C}_{\mathrm{n}} \pm \mathrm{SD}$ & $\mathrm{C}_{\mathrm{d}} / \mathrm{C}_{\mathrm{n}}$ \\
\hline $\mathrm{Ti}$ & $0.075 \pm 0.056$ & $0.019 \pm 0.049$ & 3.9 \\
\hline $\mathrm{Cr}$ & $0.033 \pm 0.025$ & $0.0039 \pm 0.0019$ & 8.2 \\
\hline $\mathrm{Mn}$ & $2.5 \pm 2.3$ & $0.11 \pm 0.11$ & 22.6 \\
\hline $\mathrm{Fe}$ & $22 \pm 15$ & $1.17 \pm 0.95$ & 18.6 \\
\hline $\mathrm{Ni}$ & $0.028 \pm 0.021$ & $0.0029 \pm 0.0017$ & 9.9 \\
\hline $\mathrm{Cu}$ & $0.497 \pm 0.374$ & $0.033 \pm 0.035$ & 14.9 \\
\hline $\mathrm{Zn}$ & $0.52 \pm 0.53$ & $0.043 \pm 0.024$ & 11.9 \\
\hline $\mathrm{Pb}$ & $0.083 \pm 0.054$ & $0.0109 \pm 0.0069$ & 7.6 \\
\hline $\mathrm{PM}_{2.5}$ & $173 \pm 85$ & $35 \pm 11$ & 4.9 \\
\hline
\end{tabular}

Elemental concentrations from the first sampling period show weekly changes. The variation of manganese $(\mathrm{Mn})$ concentrations through the first sampling period, from May $14^{\text {th }}$ (Saturday morning) to May $27^{\text {th }}$ (Thursday evening) are presented in Fig. 1. Daytime samples are marked with black columns, while night-time samples are marked with grey areas. It is evident that concentrations of metal during 
working time are much higher than concentrations for non-working time (nights and weekends). In the first week, the highest concentration was achieved on Thursday, but in the second week it was achieved on Monday, while the concentration on Thursday was very small. This shows that Mn concentration is highly dependent on the working schedule, which is very changeable.

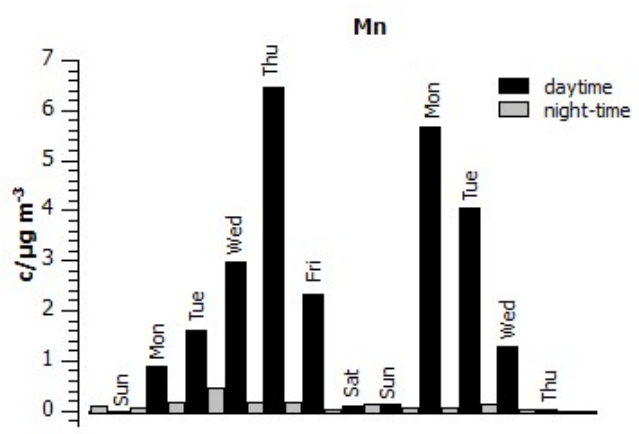

Figure 1. Weekly variations of manganese concentrations in the samples collected from May $14^{\text {th }}$ to May $27^{\text {th }}$

The main results of elemental analysis for the second sampling period are presented in Table 2. All given concentrations are in $\mu \mathrm{g} / \mathrm{m}^{3}$. The highest concentrations and ratios were measured for $\mathrm{Fe}$ and Mn. Again, Fe was found to be the dominant metal in PM2.5 and contributed significantly to the total detected metal mass loading. Iron is followed by Mn and $\mathrm{Cu}$. Fitting errors of concentrations ranged from $5 \%$ for $\mathrm{Mn}$ to $13 \%$ for $\mathrm{Pb}$.

Table 2. Average elemental and $\mathrm{PM}_{2.5}$ concentrations in the workshop $\left(\mathrm{c}_{\mathrm{w}}\right)$ and city center $\left(\mathrm{c}_{\mathrm{c}}\right)$ and their ratios for the second sampling period. Concentrations are expressed in $\mu \mathrm{g} / \mathrm{m}^{3}$

\begin{tabular}{|c|c|c|c|}
\hline & $c_{\mathrm{w}} \pm \mathrm{SD}$ & $c_{\mathrm{c}} \pm \mathrm{SD}$ & $c_{\mathrm{w}} / \mathrm{c}_{\mathrm{c}}$ \\
\hline $\mathrm{Ti}$ & $0.58 \pm 0.44$ & $0.0031 \pm 0.0044$ & 187 \\
\hline $\mathrm{Cr}$ & $0.48 \pm 0.41$ & $0.00078 \pm 0.00064$ & 600 \\
\hline $\mathrm{Mn}$ & $13 \pm 12$ & $0.0037 \pm 0.0091$ & 3641 \\
\hline $\mathrm{Fe}$ & $430 \pm 370$ & $0.075 \pm 0.059$ & 5748 \\
\hline $\mathrm{Ni}$ & $0.37 \pm 0.30$ & $0.0014 \pm 0.0016$ & 264 \\
\hline $\mathrm{Cu}$ & $5.5 \pm 4.4$ & $0.0037 \pm 0.0093$ & 1478 \\
\hline $\mathrm{Zn}$ & $0.60 \pm 0.42$ & $0.012 \pm 0.010$ & 51 \\
\hline $\mathrm{Pb}$ & $0.39 \pm 0.25$ & $0.006 \pm 0.023$ & 63 \\
\hline $\mathrm{PM}_{2.5}$ & $2200 \pm 1900$ & $20.8 \pm 7.8$ & 106 \\
\hline
\end{tabular}

Figure 2 shows temporal variations of $\mathrm{Mn}, \mathrm{Fe}$ and $\mathrm{Zn}$ concentrations during the second sampling period. Iron is a dominating constituent of metal components that are processed in the workshop and manganese is an important constituent of welding electrodes. Fe and Mn concentrations are highly connected to the working activities in the workshop. $\mathrm{Zn}$ concentrations also follow the working schedule, but variations are not so dramatic, especially for the first day of sampling. Gray columns correspond to non-working time. The line represents an average city concentration for $\mathrm{Mn}, \mathrm{Fe}$ and $\mathrm{Zn}$. It can be seen that concentrations of $\mathrm{Mn}, \mathrm{Fe}$ and $\mathrm{Zn}$ during the working time in the workshop are few order of magnitude higher than in the city center.

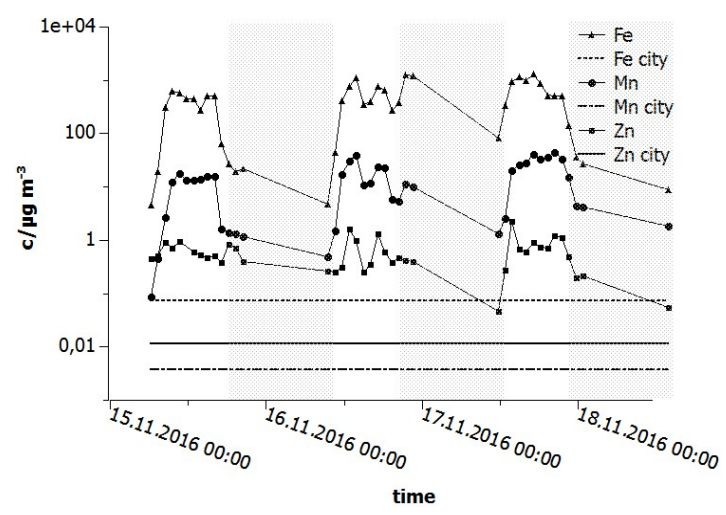

Figure 2. Temporal variations of $\mathrm{Mn}, \mathrm{Fe}$ and $\mathrm{Zn}$ concentrations in the $\mathrm{PM}_{2.5}$ samples collected in the second sampling period. Gray areas represent non-working time

Figure 3 shows the average diurnal variation in the concentration of $\mathrm{Mn}$ and Fe. Minimum concentrations are obtained during the night, but the second minimum appears between 11 and $13 \mathrm{~h}$, which corresponds to the period for lunch break. Other elements show a very similar daily pattern. Fe concentrations are also elevated in the afternoon period (17-18 PM), probably because of some additional work which was done on the second day of sampling.

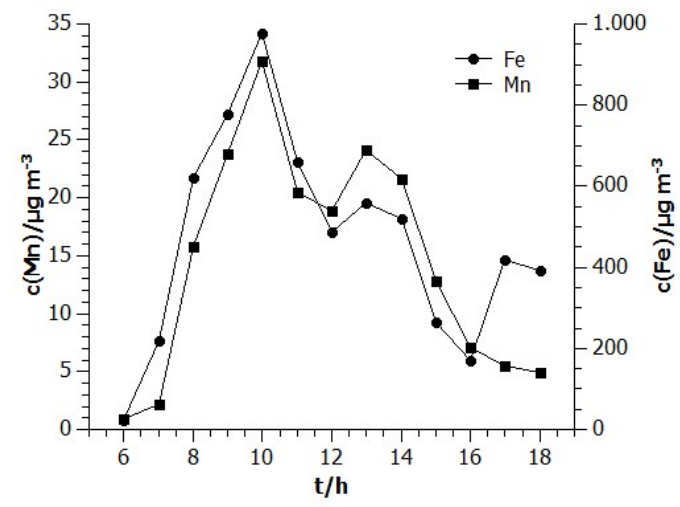

Figure 3. Diurnal variations of $\mathrm{Mn}$ and Fe concentrations

In order to obtain the size distribution, the optical particle counter measured the number concentrations of 6 different optical size ranges every 260 s. Boxwhisker plots of number concentrations for each optical size are shown in Figure 4. The majority of the particles are fine and ultrafine particles. These results are in a good agreement with the results of some previous studies [4]. 


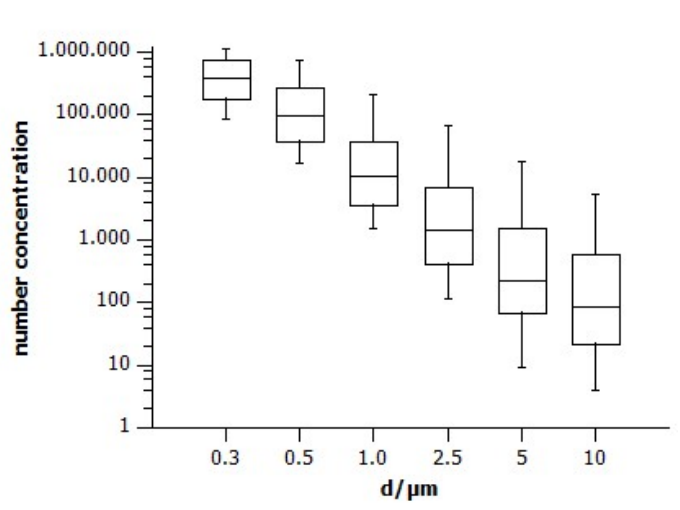

Figure 4. Typical particle size distribution of fine particulate matter $\left(\mathrm{PM}_{2.5}\right)$ in metal workshop obtained by optical particle counter

The size distribution of heavy metals can be obtained by comparing the results of elemental analysis to the data of the particle counter [15]. For that purpose, we calculated the correlations between the concentrations of a given element and of particles of a given optical size. Distributions of $\mathrm{R}^{2}$ values for $\mathrm{Fe}, \mathrm{Mn}$ and $\mathrm{Zn}$ are given in Figure 5 . For Fe, Mn and almost all the other elements, the strongest correlations are obtained for the smallest optical sizes. Therefore, it can be concluded that the metals most commonly form fine and ultrafine particles. $\mathrm{Zn}$ is the only element that shows a different pattern.

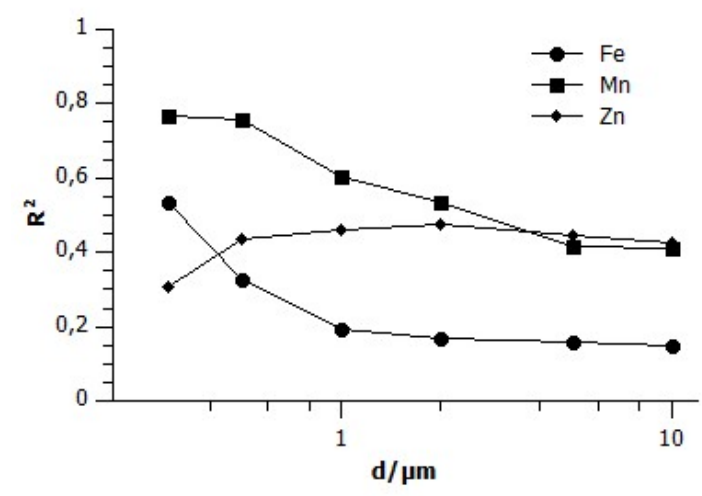

Figure 5. Distribution of $\mathrm{R}^{2}$ values between $\mathrm{Fe}, \mathrm{Mn}, \mathrm{Zn}$ and different particle sizes

Each regression analysis was based on 25 points and all correlations were statistically significant at the o.05 level. An example scatter plot of number concentration for optical size of $0.3 \mu \mathrm{m}$ and $\mathrm{Mn}$ concentrations is given in Figure 6.

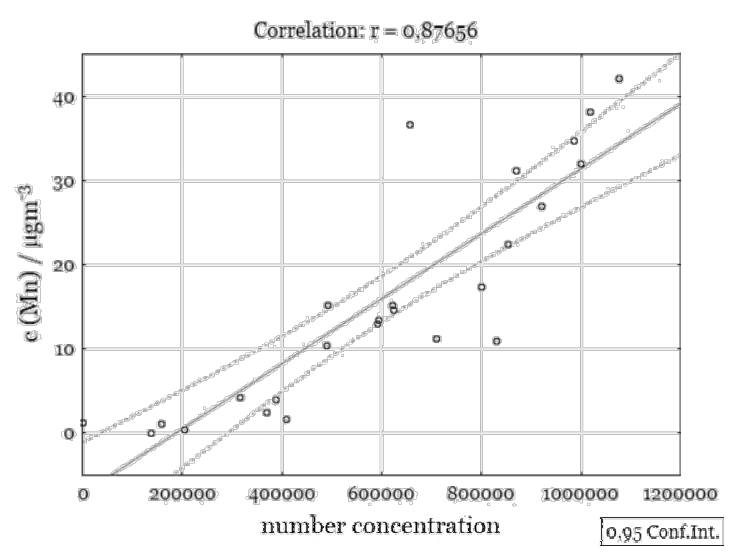

Figure 6. Correlation between number concentrations (optical size of $0.3 \mu \mathrm{m}$ ) and Mn concentrations in $\mu \mathrm{g} / \mathrm{m}^{3}$

In order to find out inter-elemental correlations, Pearson's correlation coefficients of heavy metals in $\mathrm{PM}_{2.5}$ were calculated for every pair of elements. Results are presented in Table 3. The calculation was done only for a second sampling period and included only samples measured during the working period of the day. Most of the correlation coefficients between the metals were found to be strong and statistically significant. However, there are no apparent correlations between $\mathrm{Zn}$ and $\mathrm{Cr}, \mathrm{Ni}, \mathrm{Cu}$. This indicates that these elements may come from different sources.

Table 3. Correlation matrix for heavy metals in $\mathrm{PM}_{2.5}$ samples collected in metal workshop from November $13^{\text {th }}$ until November $17^{\text {th }}$ 2016. Bold entries indicate correlations higher than 0.8 .

\begin{tabular}{|c|c|c|c|c|c|c|c|c|}
\hline & $\mathrm{Ti}$ & $\mathrm{Cr}$ & $\mathrm{Mn}$ & $\mathrm{Fe}$ & $\mathrm{Ni}$ & $\mathrm{Cu}$ & $\mathrm{Zn}$ & $\mathrm{Pb}$ \\
\hline $\mathrm{Ti}$ & 1 & $0.89^{*}$ & $0.83^{*}$ & o.92* & o.89* & o.94* & $0.49^{*}$ & $0.89^{*}$ \\
\hline $\mathrm{Cr}$ & & 1 & $0.66^{*}$ & $0.84^{*}$ & $\mathbf{0 . 8 5 ^ { * }}$ & $\mathbf{o . 8 3}^{*}$ & 0.31 & $0.76^{*}$ \\
\hline Mn & & & 1 & $0.71^{*}$ & $0.66^{*}$ & $0.86^{*}$ & $0.43^{* *}$ & $0.77^{*}$ \\
\hline $\mathrm{Fe}$ & & & & 1 & $0.96^{*}$ & $0.92^{*}$ & $0.48^{* *}$ & $0.81^{*}$ \\
\hline $\mathrm{Ni}$ & & & & & 1 & $0.93^{*}$ & 0.32 & $0.87^{*}$ \\
\hline $\mathrm{Cu}$ & & & & & & 1 & 0.39 & $0.91^{*}$ \\
\hline $\mathrm{Zn}$ & & & & & & & 1 & 0.36 \\
\hline $\mathrm{Pb}$ & & & & & & & & 1 \\
\hline
\end{tabular}

Moving the sampler position from a store-room to a distance of $5 \mathrm{~m}$ from the closest welding machine significantly affected metal concentrations. Table 4 shows average concentrations measured during working time for the first and second sampling period and their ratios. Concentrations were up to 27 times higher in the second sampling period when sampler was positioned closer to the welding machines. 
M. Čargonja et al., Analysis of aerosols in indoor working environment..., Rad. Applic., 2017, 2, 3, 220-225

Table 4. Average elemental and $\mathrm{PM}_{2.5}$ concentrations \pm standard deviation (SD) for the first $\left(c_{1}\right)$ and second $\left(c_{2}\right)$ sampling location during working time and their ratios. Concentrations are expressed in $\mu \mathrm{g} / \mathrm{m}^{3}$

\begin{tabular}{|c|c|c|c|}
\hline & $\mathrm{c}_{1} \pm \mathrm{SD}$ & $\mathrm{c}_{2} \pm \mathrm{SD}$ & $\mathrm{c}_{1} / \mathrm{c}_{2}$ \\
\hline $\mathrm{Ti}$ & $0.075 \pm 0.056$ & $0.81 \pm 0.34$ & 10.78 \\
\hline $\mathrm{Cr}$ & $0.033 \pm 0.025$ & $0.65 \pm 0.35$ & 19.82 \\
\hline $\mathrm{Mn}$ & $2.5 \pm 2.3$ & $19.9 \pm 11.6$ & 7.87 \\
\hline $\mathrm{Fe}$ & $22 \pm 15$ & $586 \pm 296$ & 26.96 \\
\hline $\mathrm{Ni}$ & $0.028 \pm 0.021$ & $0.50 \pm 0.23$ & 17.68 \\
\hline $\mathrm{Cu}$ & $0.497 \pm 0.374$ & $7.7 \pm 3.3$ & 15.46 \\
\hline $\mathrm{Zn}$ & $0.52 \pm 0.53$ & $0.75 \pm 0.46$ & 1.46 \\
\hline $\mathrm{Pb}$ & $0.083 \pm 0.054$ & $0.54 \pm 0.17$ & 6.51 \\
\hline $\mathrm{PM}_{2.5}$ & $170 \pm 85$ & $2980 \pm 1520$ & 17.29 \\
\hline
\end{tabular}

Average manganese concentrations during 8hworking periods for each sampling day in the second sampling period are presented in Table 5 . The threshold limit value (TLV) for $\mathrm{Mn}$ in working environments according to ACGIH is also shown in the table for comparison.

Table 5. Average Mn concentrations \pm standard deviation (SD) for 8h-working periods in the second sampling period and threshold limit value (TLV) according to ACGIH. Concentrations are expressed in $\mu \mathrm{g} / \mathrm{m}^{3}$

\begin{tabular}{|c|c|}
\hline & $\mathrm{c}(\mathrm{Mn}) \pm \mathrm{SD}$ \\
\hline TLV & 20.00 \\
\hline $14^{\text {th }}$ November & $12.6 \pm 4.8$ \\
\hline $15^{\text {th }}$ November & $19 \pm 11$ \\
\hline $16^{\text {th }}$ November & $28 \pm 13$ \\
\hline
\end{tabular}

\section{DisCUSSION}

During the first sampling period, heavy metal concentrations showed significant changes between working and non-working time. Working time average concentrations were up to 22 times higher than during nights and weekends (Table 1).

Hourly samples from the second sampling period show diurnal variations of aerosol concentrations, which correspond to the working schedule. Measured concentrations were significantly higher than the average values in the city center (Table 2) and the highest ratio was obtained for $\mathrm{Fe}$ (5 700 times).

Inter-elemental correlations are mostly strong and significant. Correlations between $\mathrm{Zn}$ and other elements are the weakest. Additionally, $\mathrm{Zn}$ shows the smallest indoor/outdoor ratio, as well as the smallest change within the distance. This suggests that $\mathrm{Zn}$ is the least connected to workshop activities.

Metal concentrations measured app. $5 \mathrm{~m}$ from the welding machines were up to 27 times higher than those measured app. $30 \mathrm{~m}$ from the machines. This indicates that the personal exposure to aerosols could be even higher than those measured. To confirm that, personal exposure studies should be performed.

During the second sampling period, the threshold limit value for $8 \mathrm{~h}$-working time has been exceeded in one out of three days (Table 6). This suggests that workers are probably in a high risk environment. Air quality could be improved by implementing the room ventilation [16].

\section{CONCLUSIONS}

Heavy metals in $\mathrm{PM}_{2.5}$ collected in the indoor working environment were analyzed. Concentrations of all measured metals in indoor air in our study were significantly higher than in the samples collected in the city center. The average concentrations of all measured heavy metals in indoor working environment were from 51 to 5748 times higher than those measured in the city center. The highest indoor-outdoor ratio was obtained for Fe and Mn.

Considering the heavy metal concentrations measured in indoor working environment, the attention should be paid to the health risk. Particular attention should be paid to the concentration of manganese because the preliminary measurement showed that the concentration of manganese in the indoor working environment is often approaching the permitted limit, and sometimes even exceeds that limit. An extended study should be performed in this field, including the investigation of personal exposure.

Acknowledgement: The authors would like to thank to $M r$. R. K., the director of the metallic workshop and prof. Srećko Valić from the Center for Micro and Nano Sciences and Technologies for allowing us using the balance in the Laboratory for Macromolecular Research.

\section{REFERENCES}

1. M. Žitnik et al., "Time-resolved measurements of aerosol elemental concentrations in indoor working environments," Atmospheric Environ., vol. 44, no. 38, pp. $4954-4963$, Dec. 2010.

DOI: 10.1016/j.atmosenv.2010.08.017

2. C. G. Helmis et al., "Indoor air quality in a dentistry clinic," Sci. Total Environ., vol. 377, no. 2-3, pp. 349 365, May 2007.

DOI: $10.1016 /$ j.scitotenv.2007.01.100 PMid: 17434576

3. M. Sotiriou et al., "Measurement of particle concentrations in a dental office," Environ. Monit. Assess., vol. 137, no. 1-3, pp. $351-361$, Feb. 2008.

DOI: $10.1007 /$ s10661-007-9770-7 PMid: 17505900

4. B. Berlinger et al., "Psysicochemical characterization of different welding aerosols," Anal. Bioanal. Chem., vol. 399, no. 5, pp. $1773-1780$, Feb. 2011.

DOI: $10.1007 /$ so0216-010-4185-7 PMid: 20845032

5. S. Matsuyama et al., "Microbeam analysis of individual particles in indoor working environment," $X$-Ray Spectrom., vol. 40, no. 3, pp. 172 - 175, May-Jun. 2011. DOI: $10.1002 / x r s .1311$

6. J. M. Antonini, "Health effects of welding," Crit. Rev. Toxicol., vol. 33, no. 1, pp. 61-103, 2003. DOI: $10.1080 / 713611032$ 
M. Čargonja et al., Analysis of aerosols in indoor working environment..., Rad. Applic., 2017, 2, 3, 220-225

7. J. M. Antonini, S. S. Leonard, J. R. Roberts, C. SolanoLopez, Sh H. Young, X. Shi, M. D. Taylor, "Effects of stainless steel manual metal arc welding fume on free radical production, DNA damage, and apoptosis induction," Mol. Cell. Biochem., vol. 279, no. 1, pp. 17-23, Nov. 2005 DOI: $10.1007 /$ s11010-005-8211-6

8. J. M. Antonini, A. B. Santamaria, N. T. Jenkins, E. Albini, R. Lucchini, "Fate of manganese associated with the inhalation of welding fumes: Potential neurological effects," NeuroTiyicology, vol. 27, no. 3, pp. 304-310, May. 2006

DOI: 10.1016/j.neuro.2005.09.001

9. P-E. Näslund, S. Andreasson, R. Bergström, L. Smith, B. Risberg, "Effects of exposure to welding fume: an experimental study in sheep," Eur. Respir. J., vol. 3, no. 7, pp. 800-806, Jul. 1990

10. J. D. McNeilly, M. R. Heal, I. J. Beverland, A. Howe, M. D. Gibson, L. R. Hibbs, W. MacNee, K. Donaldson, "Soluble transition metals cause the pro-inflammatory effects of welding fumes in vitro," Toxicology and Applied Pharmacology, vol. 196, no. 1, pp. 95-107, Apr. 2004

11. D.D. Cohen, E. Stelcer, D. Garton, J. Crawford, "Fine particle characterization, source apportionment and long-range dust transport into the Sydney Basin: a long term study between 1998 and 2009," Atmos. Poll. Res. vol. 2, no. 2, pp. 182-189, Apr. 2011

DOI: 10.5094/APR.2011.023

PMid: 12585507
12. M. Čargonja, T. Ivošević, I. Orlić, "Two years (2013 2015) of fine aerosol monitoring in Rijeka, Croatia," in Proc. International Congress Energy and the Environment, Opatija, Croatia, 2016, pp. $49-58$. Retrieved from: http://bib.irb.hr/datoteka/884381.Zbornik_EE2016.p df Retrieved on: Apr. 25, 2017

13. T. Ivošević, I. Orlić, I. Bogdanović Radović, "Long term fine aerosol analysis by XRF and PIXE techniques in the city of Rijeka, Croatia," Nucl. Instr. Meth. Phys. Res. B, vol. 363, pp. 119 - 123, Nov. 2015.

DOI: $10.1016 /$ j.nimb.2015.08.030

14. P. Van Espen, K. Janssens, J. Nobels, "AXIL-PC, software for the analysis of complex X-ray spectra," Chemom. Intell. Lab. Syst., vol. 1, no. 1, pp. $109-114$, Nov. 1986.

DOI: 10.1016/0169-7439(86)80031-4

15. F. Mazzei et al., "A new methodological approach: The combined use of two-stage streaker samplers and optical particle counters for the characterization of airborne particulate matter," Atmospheric Environ., vol. 41, no. 26, pp. 5525 - 5535, Aug. 2007. DOI: 10.1016/j.atmosenv.2007.04.012

16. M.-H. Lee, W. J. McClellan, J. Candela, D. Andrews, P. Biswas, "Reduction of nanoparticle exposure to welding aerosols by modification of the ventilation system in a workplace," J. Nanopart. Res., vol. 9, no. 1, pp. $127-136$, Jan. 2007.

DOI: 10.1007/s11051-006-9181-7 